\title{
Mounting Debt in a World in Overshoot: An Analysis of the Link between the Mediterranean Region's Economic and Ecological Crises
}

\author{
Alessandro Galli ${ }^{1, *}$ and Martin Halle ${ }^{2}$ \\ Global Footprint Network, International Environment House 2, 7-9 chemin de Balexert, \\ Chatelaine 1219, Geneva, Switzerland; E-Mail: martin.halle@footprintnetwork.org \\ * Author to whom correspondence should be addressed; E-Mail: alessandro.galli@footprintnetwork.org; \\ Tel.: +39-346-676-0884.
}

Received: 22 January 2014; in revised form: 27 February 2014 / Accepted: 17 March 2014 /

Published: 28 March 2014

\begin{abstract}
During the period of 1961-2008, demand for renewable resources and ecological services (as measured through the Ecological Footprint methodology) in the Mediterranean region grew by 52\% (from 2.06 to 3.12 global hectares per capita), while availability of such resources and services (or biocapacity $(\mathrm{BC})$ ) decreased by $16 \%$ (from 1.49 to 1.26 global hectares per capita). As all economic activities ultimately depend on ecological assets - such as productive land and marine areas, and the services and resources they produce - this paper presents a reflection on the economic implications of such resource and service overconsumption in the Mediterranean region. Our conclusion is that, in a world characterized by the existence of biophysical limits, risks may exist for Mediterranean economies due to the concurrence of: (1) resource scarcity; (2) increasing resource prices; and (3) challenging national economic situations.
\end{abstract}

Keywords: Ecological Footprint; resource constraints; Mediterranean region; biocapacity (BC); overshoot

\section{Overview}

Since 2008, Southern Europe's economies have struggled to recover from severe economic and financial turmoil. In much of North Africa and the Middle East, the exuberance of the Arab Spring has given way to despair. Across the Mediterranean region, street protests, revolving governments and 
tough austerity measures have done little to stem soaring unemployment, inflation, national debt and political and social upheaval.

Long ignored by decision-makers as irrelevant to economic planning and national prosperity, resource and ecosystem services limitation is likely becoming a critical factor determining a country's success in the 21 st century. The aim of this paper is thus to explore and debate the potential link between the Mediterranean region's economic and ecological situation. The Mediterranean region is considered here to include all the countries that directly border the Mediterranean Sea plus three countries, Jordan, Macedonia and Portugal, which are ecologically characterized by biomes typical of the Mediterranean region. Moreover, only countries with populations greater than 500,000 inhabitants are included in Ecological Footprint results. This region can be considered a micro cosmos, a place where multiple cultures live, where the North and the South as well as the East and the West merge. It has long been a historical crossroad of human civilizations whose influence extends far beyond its shores. It is for these reasons that we focused our analysis on the Mediterranean region: it can be considered a socio-economic laboratory, which could hold important lessons for decision-makers across the globe.

Each country is in a unique situation, yet according to Ecological Footprint Accounting (EFA) [1], each shares a common thread: The entire region is running an ecological deficit-that is, Mediterranean countries today demand more of nature than their ecosystems can provide.

EFA tracks countries' demand for biologically productive land and marine areas to produce the natural resources and services that their populations consume [2,3]. In doing so, EFA uses a consumer approach and tracks the demand for such resources and services due to production, import and export activities to then derive the Footprint of final consumption activities (as indicated in Figure 1). This aggregate demand, called a country's Ecological Footprint of consumption $\left(E F_{\mathrm{C}}\right)$, can be compared with the capacity of that country's ecosystems to supply natural resources and services - its biocapacity (BC). Both Footprint and BC are expressed in terms of hectare-equivalent units - usually referred to as global hectares (gha) — where each global hectare represents a hectare of land or water normalized to have the world-average productivity of all biologically productive land and water in a given year [4]. Expressing results in the common unit of gha allows Ecological Footprint and BC to be directly compared.

The Ecological Footprint and BC of a country thus represent two sides of an ecological balance sheet. When a country's consumption of resources and services is greater than the capacity of its ecosystems to supply them, a situation of ecological deficit is created, which is analogous to the situation of financial deficit that occurs when spending is greater than revenue. Conversely, if a country's Ecological Footprint is smaller than its BC, it is living within its ecological means. This is not sufficient to determine whether the country is sustainable [5], but it is an essential minimum condition for sustainability [6].

A recent analysis of the Mediterranean region's Ecological Footprint [7] found that from 1961 to 2008 , the per capita $E F_{\mathrm{C}}$ of an average Mediterranean resident grew by $52 \%$ (from 2.06 to $3.12 \mathrm{gha}$ ) while per capita $\mathrm{BC}$ decreased by $16 \%$ (from 1.49 gha to 1.26 gha). In 2008, the Mediterranean region's total $E F_{\mathrm{C}}$ exceeded local $\mathrm{BC}$ by more than $150 \%$. While local $\mathrm{BC}$ was able to meet about $73 \%$ of the region's demand for renewable resources and ecological services in 1961, by 2008 only $40 \%$ of 
the region's Footprint was met by local $\mathrm{BC}$. The remaining $60 \%$ was met from overconsumption of local resources, and/or import of resources and/or use of the global commons (see Figure 2).

Figure 1. Tracking production, consumption and net trade with the Ecological Footprint: The Ecological Footprint associated with each country's total consumption is calculated by summing the Footprint of its imports and its production, and subtracting the Footprint of its exports. This means that the resource use and emissions associated with producing a car that is manufactured in China, but sold and used in Italy, will contribute to Italy's rather than China's Ecological Footprint of consumption $\left(E F_{\mathrm{C}}\right)$.

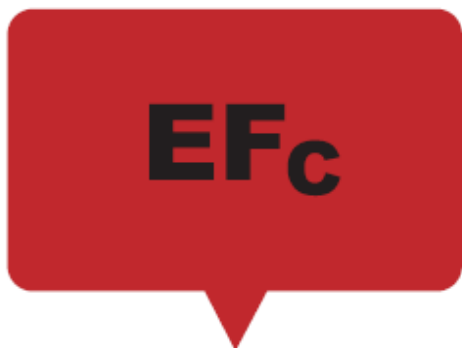

Ecological Footprint of Consumption

The Ecological Footprint of consumption indicates the consumption of biocapacity by a country's inhabitants.

In order to assess the total domestic demand for resources and ecological services of a population, we use the Ecological Footprint of consumption ( $\mathrm{EFc}$ ). EFc accounts for both the export of national resources and ecological services for use in other countries, and the import of resources and ecological services for domestic consumption.

CFc is most amenable to change by individuals through changes in their consumption behavior.

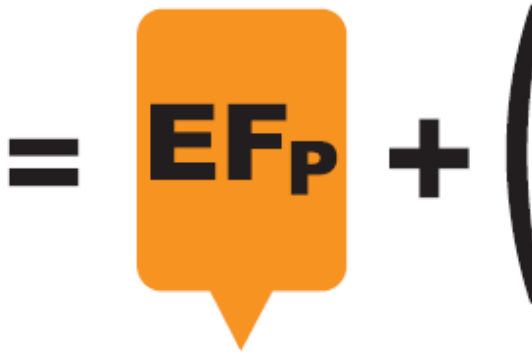

Ecological Footprint of Production

The Ecological Footprint of production indicates the consumption of biocapacity resulting from production processes within a given geographic area, such as a country or region.

It is the sum of all the bioproductive areas within a country necessary for supporting the actual harvest of primary products (cropland, pasture land, forestland and fishing grounds), the country's builttup area (roads, factories, cities), and the area needed to absorb all fossil fuel carbon emissions generated within the country.

This measure mirrors the gross domestic product (GDP). which represents the sum of the values of all goods and services produced within a couniry's borders.
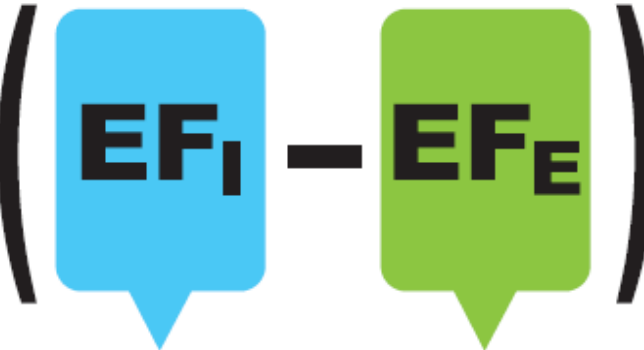

Net Ecological Footprint of Trade

The Ecological Footprint of imports and exports indicate the use of biocapacity within international trade.

Embedded in trade between countries is a use of biocapacily, the net Ecological Footprint of trade (the Ecological Footprint of imports minus the Ecological Footprint of exports). If the Ecological Footprint embodied in exports is higher than that of imports, then a country is a net exporter of renewable resources and ecological services.

Conversely, a country whose Footprint of imports is higher than that embodied in exports depends on the renewable resources and ecological services generated by ecological assets from outside its geographical boundaries

Figure 2. The Mediterranean region's Ecological Footprint of production $\left(E F_{\mathrm{P}}\right)$ and $E F_{\mathrm{C}}$ activities compared to available biocapacity (BC), 1961-2008. Comparing $E F_{\mathrm{C}}$ with BC indicates the extent of the total ecological deficit, which is made up of trade, resource overuse and use of global commons as carbon sinks. The difference between $E F_{\mathrm{C}}$ and $E F_{\mathrm{P}}$ indicates the Footprint embedded in net trade activities.

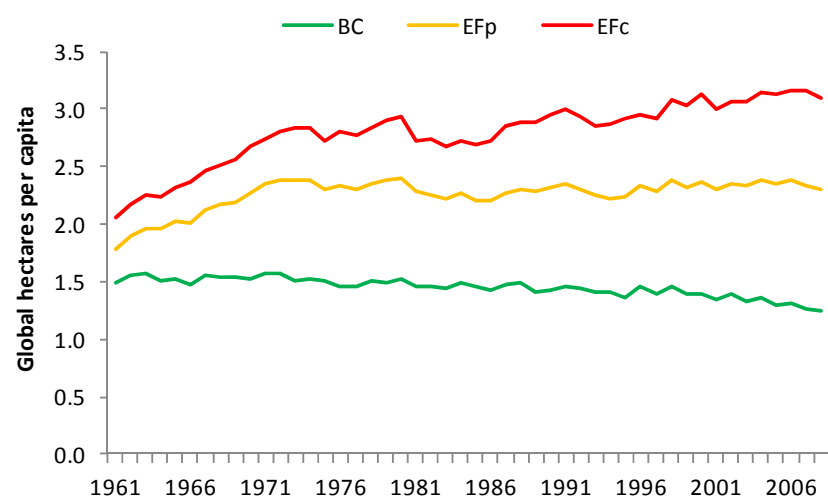


The overall ecological deficit situation shown in Figure 2 hides differences among countries and the different path these countries have experienced over time. In 1961, six countries (Algeria, Libya, Morocco, Syria, Tunisia and Turkey) in the region were characterized by ecological reserve situations, while all other countries consumed significantly more resources and services than their ecosystems were able to produce (see Figure 3).

Figure 3. Ecological deficit (red) or reserve (green) status of the Mediterranean countries in (left) 1961 and (right) 2008.
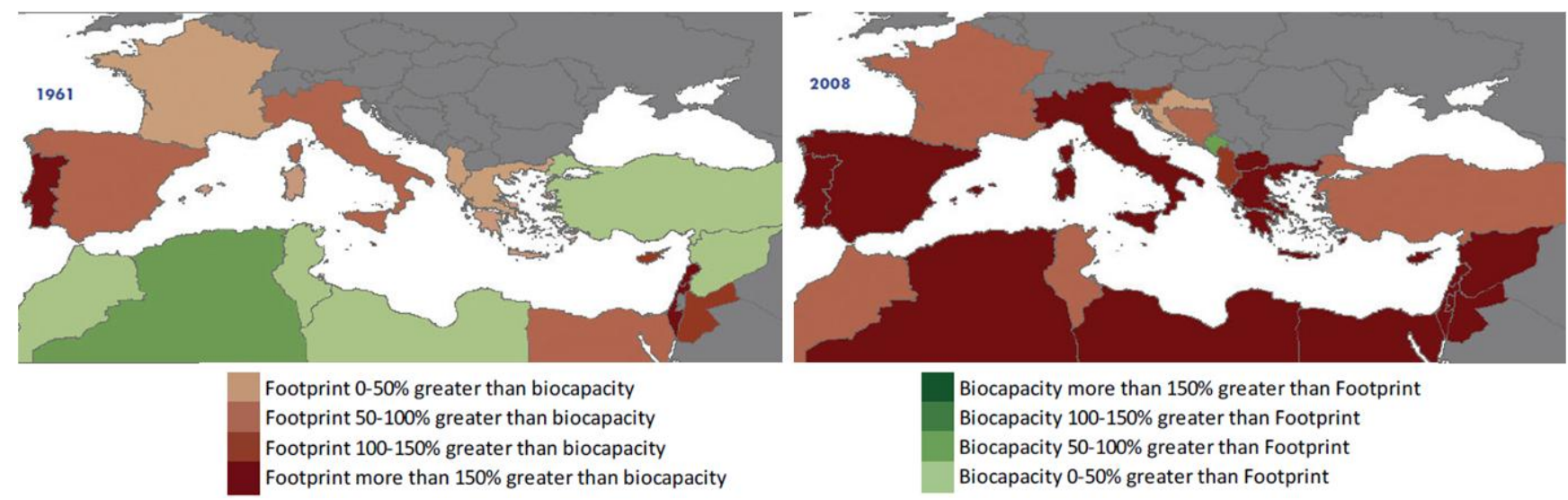

During the period of 1961-2008, the most significant shift in the ecological balance was experienced by Algeria, as this country moved from the regional-largest ecological reserve to an ecological deficit. Morocco, Libya, Syria, Tunisia and Turkey also shifted their ecological balance sheet, passing from a reserve to a deficit situation, and the other Mediterranean countries saw an increase in their ecological deficits. Our analysis seems to indicate that an ecological reserve situation could be found in Montenegro. However, we believe this is most likely due to the fact that data set for this country is not comprehensive (only data for the years 2007 and 2008 are available) nor sufficiently reliable. The largest deficit increase was experienced by Cyprus, and the smallest by Jordan. By 2008, the top five contributing countries to the regional total ecological deficit were Italy, Spain, France, Turkey and Egypt.

The observed evolution of the region's Ecological Footprint is closely linked to the rise in per capita incomes and consumption levels. Indeed, the per capita Ecological Footprint and in particular its carbon component are closely correlated with incomes [7-12]. This link is not, however, automatic as countries at similar income levels can exhibit strongly differentiated Ecological Footprints. The decisions made by citizens, governments and businesses therefore clearly have a substantial influence on the region's Ecological Footprint. Choices regarding the food, goods and services consumed, as well as the wastes generated, all affect the region's per capita Footprint as indicated in Figure 4 below.

In 2008, most of the Mediterranean region's Ecological Footprint was associated with purchases of short-lived goods and services directly paid by households $(\mathrm{HH})$ and therefore driven by individual behavior (78\% of the total Footprint). The rest of the region's Ecological Footprint was accounted for by the consumption of ecological resource and services due to long-term capital investments undertaken by businesses, HH, and governments (Gross Fixed Capital Formation, 15\%), and services directly paid by government, which may ultimately benefit $\mathrm{HH}$ such as law enforcement, education, public health, 
and defense ( $7 \%$ of the total Footprint). Among the daily consumption and service categories contributing most to the Ecological Footprint associated with household consumption in the Mediterranean region, were "Food and non-alcoholic beverages" (35\% of the household total), "Housing, water, electricity, gas and other fuels" (19\%) and human "Transportation" (19\%). Actions and policies could be prioritized in these areas to improve efficiency in the use of ecological assets and start reversing ecological deficits.

Figure 4. Breakdown of the per capita Ecological Footprint of an average Mediterranean resident, in 2008. The left chart indicates how much of the $E F_{\mathrm{C}}$ is paid for directly by household for short-lived goods $(\mathrm{HH})$, how much by government, and how much is for expenditure of long-lasting goods (GFCF). The second graph breaks down the consumption directly paid for by households $(\mathrm{HH})$ into its main categories.

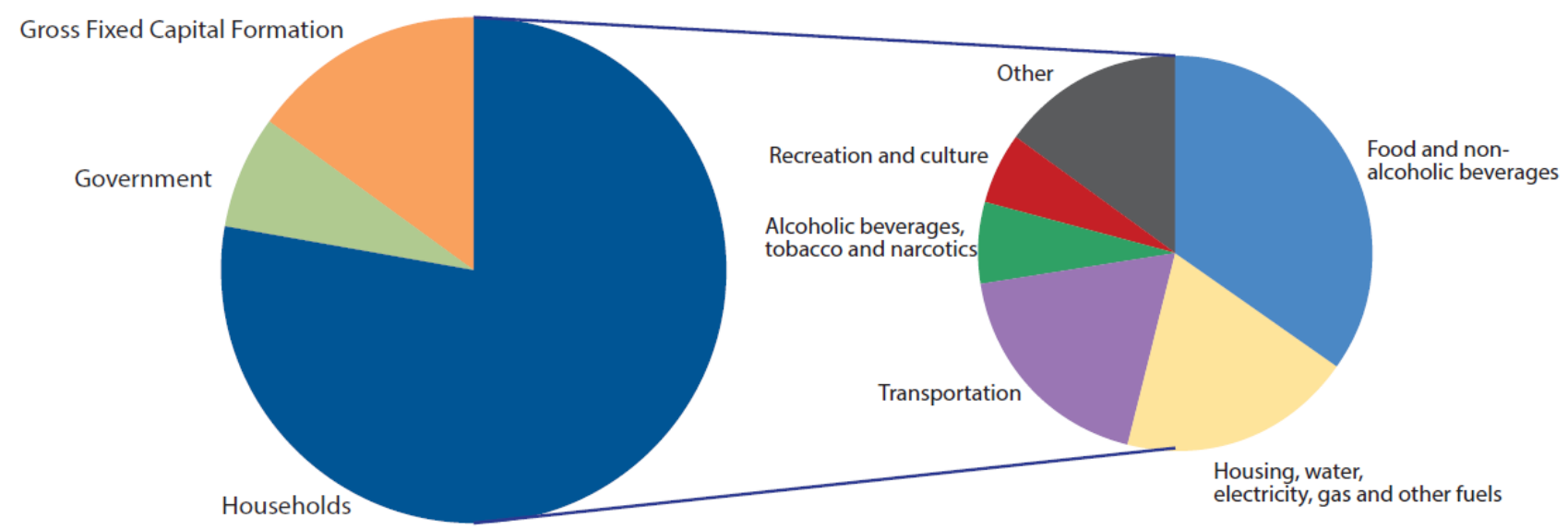

\section{Combined Ecological and Economic Limits}

Every economy ultimately depends on the availability of renewable resources and ecological services but the Mediterranean region's access to ecological assets has never been so precarious. Fifty years ago, the region used approximately $9 \%$ more ecological resources and services than its ecosystems could provide; today that figure is $98 \%$, due primarily to population growth ( $+96 \%$ during the period of 1961-2008) and per capita demand (+52\% during the same period) outpacing the growth of agricultural productivity $(+50 \%)$. Average agricultural productivity for the Mediterranean region is here calculated considering changes in the productivity of a basket of 164 primary crop products (with data from the UN Food and Agriculture Organization) in each of the 24 countries included in the analysis. Together these drivers led to a $197 \%$ increase in the total Mediterranean's Ecological Footprint during the period of 1961-2008.

Moreover, while in the 1960s the world was characterized by a global BC reserve situation allowing countries and regions facing resource scarcities to import them reliably and cheaply from surplus regions; this is no longer the case. Today, the world is in a situation of global overshoot with humanity consuming over 1.5 times more natural resources and services than can be renewed $[2,13]$.

As a result, resources are getting scarcer globally and Mediterranean economies are experiencing a weakening in economic performance. The median yearly growth rate of Mediterranean countries between 2008 and 2012 was only $0.5 \%$, a fraction of the median yearly growth rate of previous periods 
(see Figure 5). When consumption exceeds local availability, countries will either increase the pressure on their own productive ecosystems to produce more resources or turn to international trade to meet their demand for natural capital. Access to outside resources, however, is limited by: (a) the global natural capital budget; and (b) the ability of these countries to pay for increased imports of these assets at a time when global scarcity is maintaining historically high commodity prices [14].

Figure 5. Median yearly growth rate of Mediterranean countries, five-year averages. The columns represent the median growth rate of gross domestic product (GDP) for all Mediterranean countries for which data is available, averaged out over a five-year period.

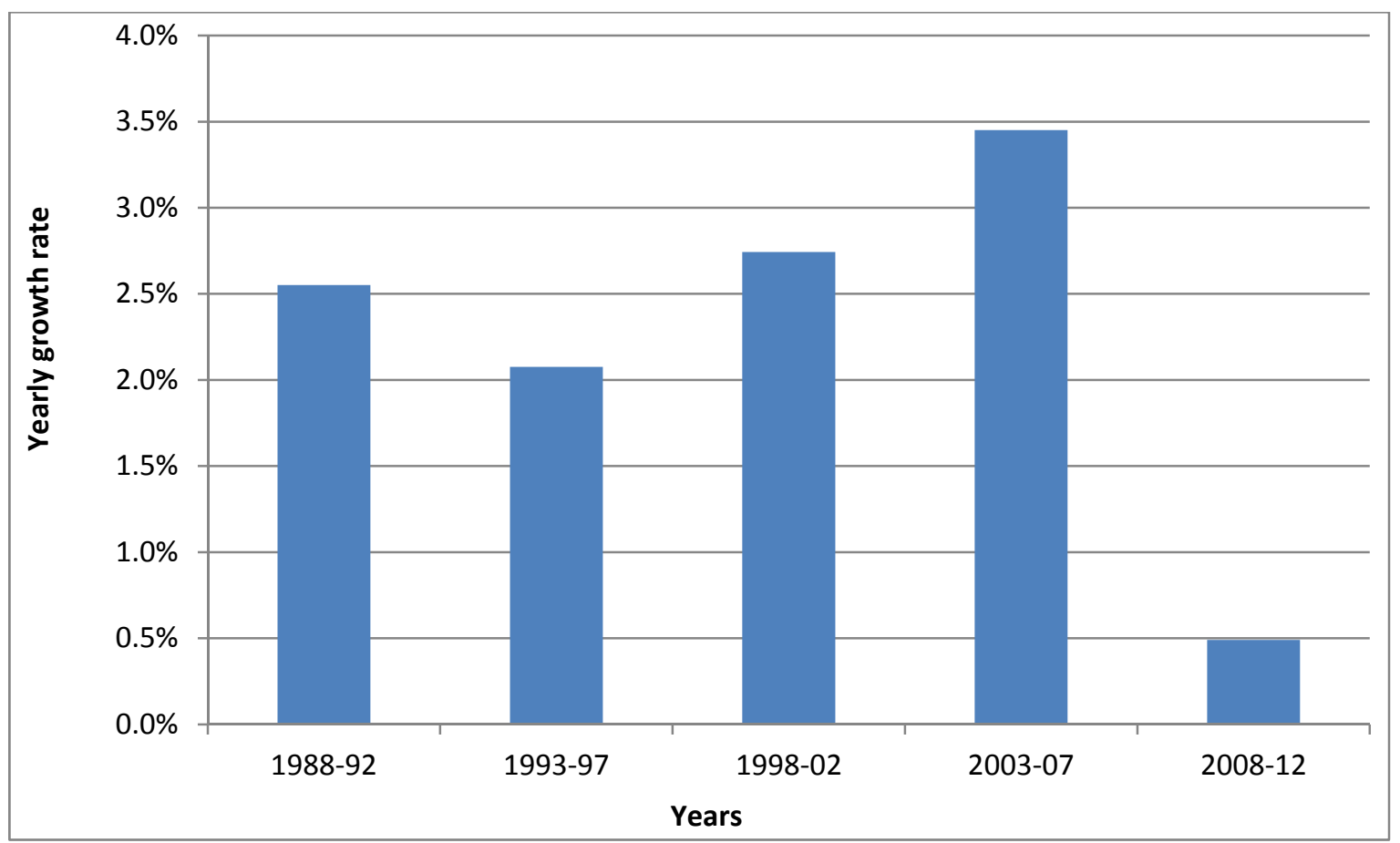

Our analysis suggests that the conjunction of the ecological crisis of overconsumption with the economic crisis is causing an underlying problem for the region and its countries:

- "Physical limits" exist and they might impede long-term access to external resources. The Mediterranean's net dependence on external resources has massively increased during the period of 1977-2008 (+70\%): during this period, the Ecological Footprint of imports went from nearly 30 to approximately 140 million gha, while that of exports went from nearly 24 to approximately 88 million gha. Moreover, the region's major trade partners have shifted from countries and regions with $\mathrm{BC}$ reserves (e.g., Canada, Scandinavia and South America) to those who are running $\mathrm{BC}$ deficits themselves (e.g., USA, China and non-Mediterranean European nations) as shown in Figure 6. The significance of this shift is that exporting nations might be increasingly unable to meet their own needs, which would restrict Mediterranean countries' ability to import resources from those countries. Indeed, there have been several instances in the past decade of large food grain exporting countries implementing temporary export bans when the security of supply of their own citizens was threatened [15].

- "Economic limits" exist as well. Globally, rising populations and income levels are causing total demand for natural resources to increase. As the increase in supply of these resources has lagged 
behind the growth in demand, the prices of many commodities have increased sharply [16]. The growing demand of the Mediterranean population for resources has therefore become considerably more expensive to satisfy at a time when many Mediterranean countries are experiencing a weakening of their economic performance.

Figure 6. Ecological Footprint embedded in (left graphs) imports from and (right graphs) exports to major trade partners of the Mediterranean region in (top graphs) 1977 and (bottom graphs) 2008. The ecological deficit (red) or reserve (green) status of those trading partners is also provided. United Nations Commodity Trade Statistics Database (UN Comtrade) and Food and Agricultural Organization (FAO) bilateral trade data were used to calculate the Ecological Footprint embedded in exports. Intra-regional trade was not included in the analysis. For ease in visualization, only the three main traded Footprint components are reported in the maps.

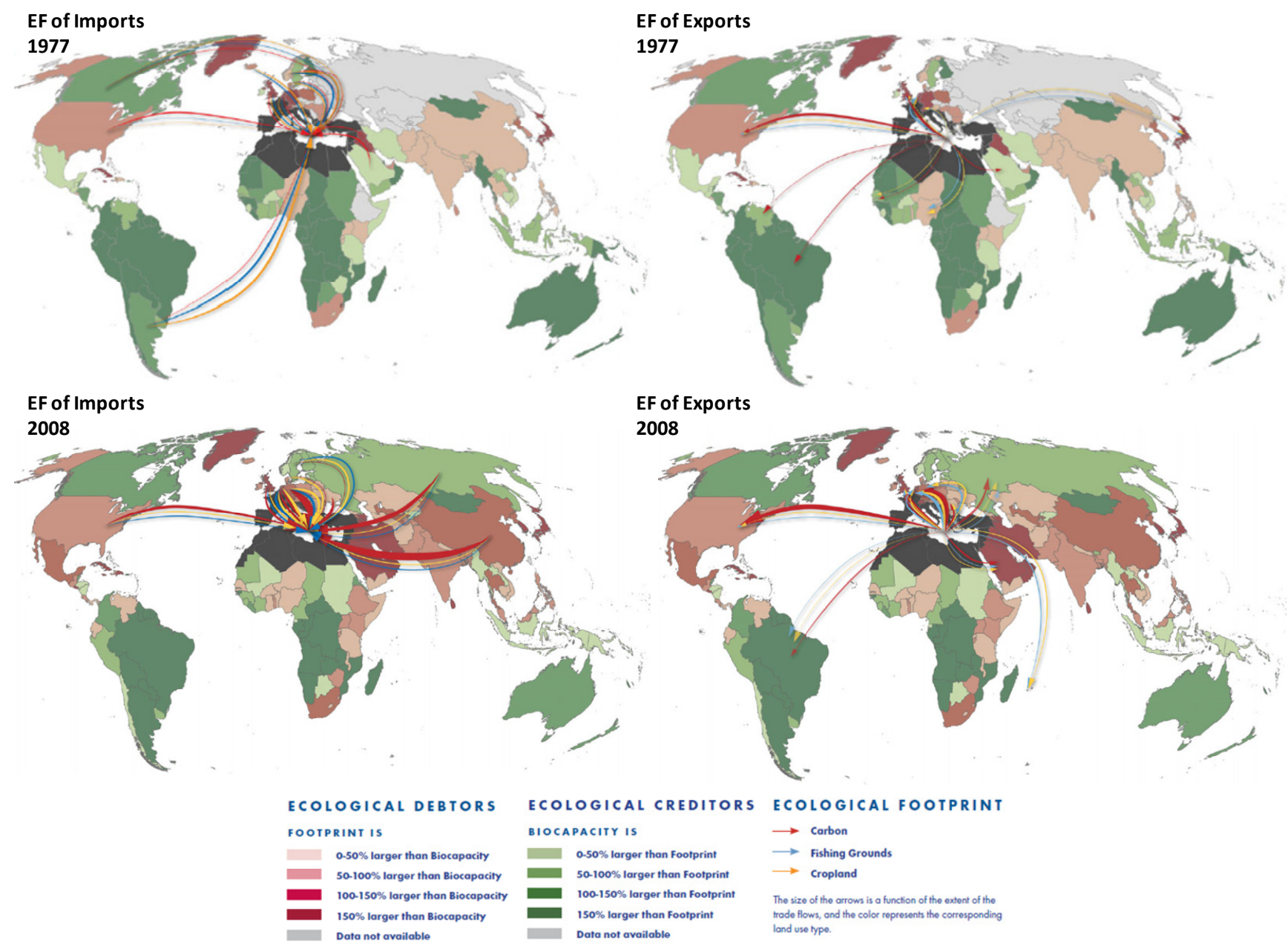

Resource constraints cannot by themselves explain the political crises that have affected many of the region's countries in the past few years but they are playing an increasingly central role as argued by several authors (e.g., [17]), including authors from outside the Mediterranean region (e.g., [18-21]). For instance, numerous articles have already linked drought and climate change to Syria's civil war (e.g., [22]) or argued that resource scarcity has had a direct impact on Egypt's failing economy and ongoing social unrest $[23,24]$. 
While the Syrian and Egyptian cases are surely unique, a recent analysis of the region's supply of and demand on its natural resources [25], leads us to conclude that if other Mediterranean nations fail to track and manage their demands on ecological assets, their economies will become ever more fragile - which can, in time, expose them to social and political instability.

\section{Discussion}

Ecological deficits did not constitute significant strain on the economic performance of most countries in recent decades. Global BC was still sufficient to supply the natural resources and services that humanity demanded of it, which allowed most "ecological debtor" countries to turn to cheap imports to sustain these demands. However, since the early 1970s, global demand for resources has outstripped what the biosphere can renew $[2,26]$. Today, humanity's annual resource use is equivalent to what 1.5 Earths can replenish in a year $[2,13]$, and the increasing global scarcity is affecting the price of essential natural resources [16,27,28].

In the current situation, some countries are still better off than others. Even as resource constraints tighten, many ecological debtor countries have the wealth to afford what they need. Yet this competition for access to resources is heating up at a time when the economic performance of many Mediterranean countries is weakening. If world commodity prices continue to be as volatile as they have been over the past ten years as projected in [27-31], the Mediterranean region is likely to face a serious risk of supply disruption.

Commodity price volatility affects both commodity producers and consumers and countries may experience short-term profits or losses depending on their economic profiles. Expenditures incurred from importing essential food products, for example, might be equaled or surpassed by oil export earnings. However, our analysis of price volatility impacts tells us that almost every country in the Mediterranean region would experience a negative impact on its trade balance as a result of generalized commodity price increases.

Assuming an unvaried demand, we calculate that a sudden $10 \%$ increase in commodity prices - a modest estimate given the fluctuations of the last decade-would worsen Mediterranean countries' trade balance by the equivalent of $0.1 \%-2.4 \%$ of their national gross domestic product (GDP).

Egypt, for instance, could maintain its current resource demands by paying an additional annual import bill equivalent to $0.65 \%$ of its GDP. Spain's annual increase would be equivalent to $0.4 \%$ of its GDP. Italy would have to pay the equivalent to $0.46 \%$ of its GDP annually, Greece $0.43 \%$ and Morocco $1.08 \%$. Jordan, the hardest hit in the region, would have to pay the equivalent to $2.4 \%$ of its GDP annually.

Only the Mediterranean region's two primary oil and gas producing nations-Libya and Algeria-would benefit from the price increase, reaping additional export earnings from more costly energy commodities. As the supply of natural resources is increasingly unable to satisfy the demand for them, however, markets become more responsive even to small signals resulting in growing commodity price volatility [32]. Even net resource exporters, such as Algeria and Libya, are therefore exposed to the consequences of growing global resource scarcity. As uncertainty regarding future revenues increases the incentives to invest in improvements to productive capacity is weakened, perpetuating the situation of scarcity even further. 


\section{Conclusions}

Running ever larger concurrent economic and ecological deficits can have severe impacts. Mediterranean economies are likely to come under greater stress as they compete for access to essential resources. Some countries simply might not be able to afford to keep up with increasing costs, and will turn to overharvesting to meet their resource needs.

This could lead to even greater environmental pressures in the region. A government that faces a growing negative trade balance, or one that starts to feel the pinch of tightening resource constraints, may start depleting its country's resource base to meet its population's demand. The resulting depletion of productive ecosystems would constitute, in turn, an even more severe threat to the region's resource supply.

We live in a world where daily media reports trumpet the smallest shift in the NASDAQ, Nikkei and other indices. A $0.05 \%$ increase in the GDP of a nation is reported as a positive performance. It is, therefore, difficult to understand how we can ignore the risks of an entire region's threatened access to resources and services, critical to their already struggling economies.

There is still time to mitigate these risks. However, the longer Mediterranean countries fail to manage their resource use and ecological assets, and the more they liquidate their natural capital, the more painful the inevitable reforms will be. While we acknowledge that the current analysis does not yet offer suggestions on how to mitigate the risks, we argue that it provides a macro-level guidance to help identify the areas were policies and actions should be prioritized for risks' mitigation. These areas are: (1) food and non-alcoholic beverages; (2) housing, water, electricity, gas and other fuels; and (3) transportation.

\section{Acknowledgments}

Support from MAVA Foundation pour la Nature (Grant No. 13/09) is gratefully acknowledged. Authors also wish to thank Scott Mattoon for his precious work on a preliminary draft of the manuscript and English corrections. Finally, we would like to gratefully thank the four anonymous reviewers of this paper for their comments.

\section{Author Contributions}

Alessandro Galli designed the research. Alessandro Galli and Martin Halle compiled and analyzed the data and wrote the paper.

\section{Conflicts of Interest}

The authors declare no conflict of interest.

\section{References}

1. Wackernagel, M.; Onisto, L.; Bello, P.; Callejas Linares, A.; López Falfán, I.S.; García, J.M.; Suárez Guerrero, A.I.; Suárez Guerrero, M.G. National natural capital accounting with the ecological footprint concept. Ecol. Econ. 1999, 29, 375-390. 
2. Borucke, M.; Moore, D.; Cranston, G.; Gracey, K.; Katsunori, I.; Larson, J.; Lazarus, E.; Morales, J.C.M.; Wackernagel, M.; Galli, A. Accounting for demand and supply of the biosphere's regenerative capacity: The National Footprint Accounts' underlying methodology and framework. Ecol. Indic. 2013, 24, 518-533.

3. Wackernagel, M.; Schulz, B.; Deumling, D.; Linares, A.C.; Jenkins, M.; Kapos, V.; Monfreda, C.; Loh, J.; Myers, N.; Norgaard, R.; et al. Tracking the ecological overshoot of the human economy. Proc. Natl. Acad. Sci. USA 2002, 99, 9266-9271.

4. Galli, A.; Kitzes, J.; Wermer, P.; Wackernagel, M.; Niccolucci, V.; Tiezzi, E. An exploration of the mathematics behind the Ecological Footprint. Int. J. Ecodyn. 2007, 2, 250-257.

5. Galli, A.; Wiedmann, T.; Ercin, E.; Knoblauch, D.; Ewing, B.; Giljum, S. Integrating Ecological, Carbon and Water footprint into a "Footprint Family" of indicators: Definition and role in tracking human pressure on the planet. Ecol. Indic. 2012, 16, 100-112.

6. Bastianoni, S.; Niccolucci, V.; Neri, E.; Cranston, G.; Galli, A.; Wackernagel, M. Sustainable Development: Ecological Footprint in Accounting. In Encyclopedia of Environmental Management; Taylor \& Francis: London, UK, 2013; pp. 2467-2481. Available online: http://www.tandfonline. com/doi/abs/10.1081/E-EEM-120047347 (accessed on 26 February 2014).

7. Galli, A.; Moore, D.; Brooks, N.; Iha, K.; Cranston, G. Mediterranean Ecological Footprint Trends; Global Footprint Network (GFN): Oakland, CA, USA, October 2012. Available online: http://www.footprintnetwork.org/images/article_uploads/Mediterranean_report_FINAL.pdf (accessed on 11 December 2013).

8. Niccolucci, V.; Tiezzi, E.; Pulselli, F.M.; Capineri, C. Biocapacity vs Ecological Footprint of world regions: A geopolitical interpretation. Ecol. Indic. 2012, 16, 23-30.

9. Niccolucci, V.; Pulselli, F.M.; Tiezzi, E. Strengthening the Threshold Hypothesis: Economic and biophysical limits to growth. Ecol. Econ. 2007, 60, 667-672.

10. Galli, A.; Kitzes, J.; Niccolucci, V.; Wackernagel, M.; Wada, Y.; Marchettini, N. Assessing the global environmental consequences of economic growth through the Ecological Footprint: A focus on China and India. Ecol. Indic. 2012, 17, 99-107.

11. Patrizi, N.; Capineri, C.; Rugani, B.; Niccolucci, V. Socio-economic Design and Nature: A possible representation through ecological footprint. WIT Trans. Ecol. Environ. 2010, 138, 527-534.

12. White, T.J. Sharing resources: The global distribution of the Ecological Footprint. Ecol. Econ. 2007, 64, 402-410.

13. Biodiversity, Biocapacity and Better Choices; Living Planet Report 2012; WWF: Gland Switzerland; Global Footprint Network (GFN): Oakland, CA, USA; Zoological Society of London: London, UK, 2012. Available online: http://awsassets.panda.org/downloads/1_lpr_2012_online_full_size_ single_pages_final_120516.pdf (accessed on 26 February 2014).

14. Wackernagel, M.; Galli, A. Ecological footprint: Economic performance and resource constraints. Glob. Dialogue 2012, 14, 12-26. Available online: http://www.worlddialogue.org/content.php? $\mathrm{id}=512$ (accessed on 26 February 2014).

15. Rocha, N.; Giordani, P.; Ruta, M. Export Policy and Food Price Escalation, 2012. Available online: http://www.voxeu.org/article/world-food-prices-and-protectionism (accessed on 21 January 2013). 
16. World Bank Commodity Price Data (Pink Sheet), 2013. Available online: http://data.worldbank.org/data-catalog/commodity-price-data (accessed on 21 January 2013).

17. Aly, H.; Strazicich, M. Did the Global Financial Crisis and Recession Contribute to the Uprisings in North Africa? Working Paper No. 651; Economic Research Forum: Antalya, Turkey, March 2011. Available online: http://www.erf.org.eg/CMS/uploads/pdf/651.pdf (accessed on 26 February 2014).

18. Kohl, B.; Farthing, L. Material constraints to popular imaginaries: The extractive economy and resource nationalism in Bolivia. Polit. Geogr. 2012, 31, 225-235.

19. Lou, B.; Ulgiati, S. Identifying the environmental support and constraints to the Chinese economic growth-An application of the Emergy Accounting method. Energy Policy 2013, 55, 217-233.

20. Peretto, P.F. Resource abundance, growth and welfare: A Schumpeterian perspective. J. Dev. Econ. 2012, 97, 142-155.

21. Kerschner, C.; Prell, C.; Feng, K.; Hubacek, K. Economic vulnerability to Peak Oil. Glob. Environ. Chang. 2013, 23, 1424-1433.

22. Werrell, C.; Femia, F. One-Stop List of Resources on Syria, Drought, Climate Change and Unrest. The Center for Climate \& Security, 2013. Available online: http://climateandsecurity.org/2013/09 /12/update-coverage-on-syria-drought-climate-change-and-unrest/ (accessed on 11 December 2013).

23. Ahmed, N.M. How Resource Shortages Sparked Egypt's Months-Long Crisis? Atlantic Media Company: Washington, DC, USA, August 2013. Available online: http://www.theatlantic.com/ international/archive/2013/08/how-resource-shortages-sparked-egypts-months-long-crisis/278802/ (accessed on 11 December 2013).

24. Ahmed, N.M. Economists Forecast the End of Growth; The Guardian: London, UK, July 2013. Available online: http:/www.theguardian.com/environment/earth-insight/2013/jul/19/economyend-growth-resource-scarcity-costs (accessed on 11 December 2013).

25. Galli, A.; Halle, M.; Mattoon, S.; Wackernagel, M. Physical and Financial Limits to Resource Access and Utilization: The Case of the Mediterranean Economies; Presented at the World Resource Forum, Davos, Switzerland, 6-9 October 2013. Available online: http://worldresourcesforum.org/files/WRF2013/Full\%20Papers/Galli\%2CHalle\%2CMattoon\%26 Wackernagel_WRF2013.pdf (accessed on 26 February 2014).

26. National Footprint Accounts 2012 Edition; Global Footprint Network (GFN): Oakland, CA, USA, 2012. Available online: http://www.footprintnetwork.org (accessed on 11 December 2013).

27. Dobbs, R.; Oppenheim, J.; Thompson, F.; Mareels, S.; Nyquist, S.; Sanghvi, S. Resource Revolution: Tracking Global Commodity Markets; McKinsey Global Institute, 2013. Available online: http://www.mckinsey.com/insights/energy_resources_materials/resource_revolution_tracking_glo bal_commodity_markets (accessed on 11 December 2013).

28. Allouche, J. The sustainability and resilience of global water and food systems: Political analysis of the interplay between security, resource scarcity, political systems and global trade. Food Policy 2011, 36, S3-S8.

29. Grantham, J. Time to Wake Up-Days of Abundant Resources and Falling Prices Are Over Forever; The Oil Drum, 2011. Available online: http://www.theoildrum.com/node/7853 (accessed on 19 February 2014). 
30. Lee, B. The Geopolitics of the Modern Resource Boom; Americas Quarterly: North Hollywood, CA, USA, 2013. Available online: http://americasquarterly.org/content/geopolitics-modern-resourceboom (accessed on 11 December 2013).

31. Salisbury, I. Our Chat with Jeremy Grantham. The Wall Street Journal, New York, NY, USA, 20 September 2013. Available online: http:/online.wsj.com/news/articles/ SB10001424127887323665504579032934293143524 (accessed on 11 December 2013).

32. Caldecott, B.; Howarth, N.; McSharry, P. Stranded Assets in Agriculture: Protecting Value from Environment-Related Risks; Smith School of Enterprise and the Environment, University of Oxford: Oxford, UK, August 2013. Available online: http://www.smithschool.ox.ac.uk/research/strandedassets/Stranded\%20Assets\%20Agriculture\%20Report\%20Final.pdf (accessed on 21 January 2013).

(C) 2014 by the authors; licensee MDPI, Basel, Switzerland. This article is an open access article distributed under the terms and conditions of the Creative Commons Attribution license (http://creativecommons.org/licenses/by/3.0/). 